\title{
Historiography in the Margins and the Reader as a Touchstone
}

Studying the relationship between ancient historians and their audience is not always an easy task. ${ }^{1}$ One way is to approach the matter from the author's point of view, by closely examining the passages that explicitly anticipate the possible reactions of their audience. One can thus form an idea of how a historical work could be received, keeping in mind, though, that this is the representation historians had or pretended to have, not necessarily how their readers actually were.

Another way consists in using the global trends that can be found in historical works as clues to the taste of the author, but also of the audience, for the literary dimension of the genre also implied to try and write in a manner that would make the work pleasant. This method is especially effective when some passages contradict the methodological claims made somewhere else: Tacitus is openly defiant towards portents, ${ }^{2}$ but nevertheless mentions them, probably because his public would not accept a total omission.

Eventually there is a third way that implies to have a look somewhere else, examining texts that work as mirrors: they do not belong to the historiographical genre, but are related to it, because they parody, theorize or give instructions about it. Among them is the Apocolocyntosis Diui Claudii by Seneca, for its grotesque narration of what happened to the emperor Claudius after his death, particularly when alluding to Drusilla's deification, plays, as I will demonstrate, on many characteristics of ancient historiography and appears to be "a travesty of historical enquiry". ${ }^{3}$ The result is a parody according to the modern sense of the word, ${ }^{4}$ an imitative genre most useful when one wants to understand the reception of literature, because a parodist has to play with the commonly recognized characteristics of the imitated works, for the reader to identify them and enjoy the mocking. ${ }^{5}$ A parody thus does not take up the way authors conceived what they wrote, but the way their audience received their works; especially it plays on the points that could raise criticism, for no audience likes something widely acknowledged to be mocked.

As a consequence, what does a text like the Apocolocyntosis tell about the reception of historical texts and the way their audience considered ancient historians? What can we infer about the declarations found in works of historiography? It

1 I am deeply grateful to V. Liotsakis and A. Kachuck for their suggestions and corrections. Of course, all remaining errors and inaccuracies are my own.

2 Cf. Grimal 1989.

3 Cf. Whitton 2013, 157.

4 Cf. Householder 1944 for its meaning in Antiquity.

5 Cf. Thompson 1986, 15 and 17-18 for the difficulty to fully understand this "encoding/decoding" process. The reference studies on parody in general are Rose 1979, Genette 1982 and Hutcheon 1985. 
seems that neither historians nor their readers were naive about the way history was actually written, with a remarkable continuity at least from Cicero's time to Lucian's.

The historical and the literary dimensions of the Apocolocyntosis Diui Claudii have already been much studied. Scholars have examined its genre, the Menippean satire ${ }^{6}$ the influence it had on successive authors, ${ }^{7}$ its intended audience, ${ }^{8}$ the details it contains about the circumstances of Claudius' death, ${ }^{9}$ and the historical basis of his portrayal. ${ }^{10}$ Yet, these perspectives do not seem to have been combined to investigate the historiographical field, in spite of possible comparisons with works like Tacitus' Annales or Suetonius' Diuus Claudius. Seneca's text does not claim to be historical, but its first part seems to parody the habits of historiography, with a very revealing beginning (Sen. Apoc. 1.1):

Quid actum sit in caelo ante diem III. idus octobris anno nouo, initio saeculi felicissimi, uolo memoriam tradere.

What happened in heaven on the third day before the Ides of October, on this new year that was the beginning of a most happy era, is what I want to pass on to the common memory. (translations are my own)

This sentence features many elements that are typical of historical prologues: a clause that announces the subject of the work, ${ }^{11}$ a date quickly following, ${ }^{12}$ and the use of memoria ${ }^{13}$ and tradere ${ }^{14}$ that are stock Latin words to designate historical activity. ${ }^{15}$ Seneca is thus absolutely explicit about the genre he is about to imitate: even the presentation of the current reign as a new beginning and a most happy

6 Cf. Moretti 2003.

7 Cf. Renard 1937.

8 Cf. Whitton 2013.

9 Cf. Aveline 2014.

10 Cf. Fishwick 2002.

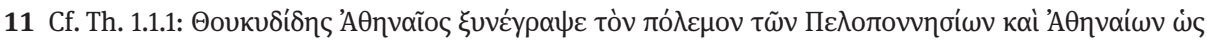

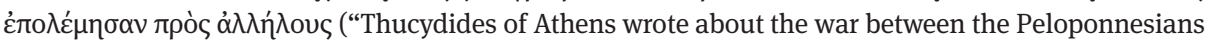
and the Athenians, how they fought against each other").

12 Cf. Tac. Hist. 1.1.1: Initium mihi operis Seruius Galba iterum, Titus Vinius consules erunt ("The beginning of my work will be the second consulate of Servius Galba and the first of Titus Vinius"). 13 Cf. Liv. pr. 3: Vtcumque erit, iuuabit tamen rerum gestarum memoriae principis terrarum populo pro uirili parte et ipsum consuluisse ("Whatever it be, however, I will be glad to have also dealt myself, in turn, with the memory of the accomplishments of the first nation in the world").

14 Cf. Tac. Ag. 1.1: Clarorum uirorum facta moresque posteris tradere ("To pass on to posterity the actions and the habits of great men"). This clause is also a quotation of the first sentence of Cato the Elder's Origines.

15 Cf. Duchêne 2020. 
era is a topos of imperial historiography, ${ }^{16}$ for emperors were the ones who gave or forbade free access to information ${ }^{17}$ and afterwards decided whether the work should have an open diffusion or not. ${ }^{18}$

The parody goes on with the following sentences, that correspond to typical claims made by historians (Apoc. 1.1 and 1.3):

Nihil nec offensae nec gratiae dabitur. haec ita uera [...]. ab hoc ego quae tum audiui certa, clara affero [...].

Nothing will be presented either to offend or gain a favor. These elements so true [...]. I report confidently and clearly what I heard then from him [...].

Ancient historians very keenly denied having prejudices, especially at the beginning of their work. ${ }^{19}$ Since ancient historiographical texts followed the evaluation criteria of rhetorics and were mainly based on verisimilitude, ${ }^{20}$ being unbiased was very important, ${ }^{21}$ for it assured the reader that the narration was as close to the facts as possible. ${ }^{22}$ This importance of verisimilitude explains why, when incredible elements are to appear in their text, ancient historians very often try to prevent any accusation of forgery by insisting on the solidity of their information. ${ }^{23}$ In the passage above, Seneca takes up all these "professional" claims, by affirming he has no other goal than saying what actually happened (nihil nec offensae nec gratiae dabitur), emphasizing the veracity of what he is about to tell (haec ita uera) and the fact that his text contains no distortion (clara).

This passage also exemplifies another characteristic of historiographical texts: allusions to the researches made before the redaction. The relative clause $a b$ hoc quae audiui specifies that Seneca did not copy something he found in a book or heard from someone else, but really spoke with the alleged witness, playing here

16 Cf. Tac. Ag. 3.1: Nunc demum redit animus; sed quamquam primo statim beatissimi saeculi ortu Nerua Caesar res olim dissociabilis miscuerit, principatum ac libertatem ("Only now do we live again; but even though immediately, at the very beginning of this most blessed era, Nerva Caesar mixed things impossible to associate before, Principate and freedom").

17 Cf. Marincola 1997, 86-95.

18 Cf. the Cremutius Cordus affair in Tac. Ann. 4.34-35.

19 Cf. for instance the famous sine ira et studio at Tac. Ann. 1.1.3.

20 Cf. Woodman 1988, $70-76$.

21 Cf. Marincola 1997, 158-175.

22 Of course, given the political use the ancients made of historiography (cf. Wiseman 1979), deformations were common, but they could not be obvious. For an example with Tacitus, cf. Devillers 1994.

23 Cf. Tac. Hist. 2.50.2: Ut conquirere fabulosa et fictis oblectare legentium animos procul grauitate coepti operis crediderim, ita uolgatis traditisque demere fidem non ausim ("As much as I would think far from the seriousness of the work I am starting to look for marvels and entertain with fictions the minds of my readers, I would not either discredit elements that have been diffused and passed on"). Tacitus here speaks about a bird which would not leave a sanctuary before Otho committed suicide. 
with the famous Thucydidean insistence on privileging first-hand testimonies. ${ }^{24}$ Indeed, a few sentences before, Seneca is able to explain how to question his man (Apoc. 1.3):

Hunc si interrogaueris, soli narrabit. coram pluribus nunquam uerbum faciet.

This man, if you want to question him, only privately will he tell you the story. In front of more people he will never say a word.

Such details on the precise circonstances needed should the reader interrogate the witness imply that this is how Seneca managed to actually hear him tell his story: thus, the use of audiui a bit later seems credible. In the meantime, he also highlights the value of his work - what he is about to tell is not a well-known tale: he had to tenaciously look for someone who knew it and find a way to have him talk.

But displaying brand new information ${ }^{25}$ is only one side of the medal for ancient historians: they can also refuse to repeat something that is widely known, so as not to tire their audience. ${ }^{26}$ It is then not surprising to also see Seneca refuse to give useless details about the imperial funeral (Apoc. 5.1):

Quae in terris postea sint acta superuacuum est referre. scitis enim optime nec periculum est ne excidant quae memoriae gaudium publicum impresserit.

It is useless to report what happened on earth afterwards, for you know it very well and there is no danger that the events which left the memory of such a public joy be forgotten.

He plays here on what his audience supposedly already knew, so as to avoid useless repetitions. This process is the basis of information display in ancient historical texts ${ }^{27}$ and, by openly deciding what to tell and what to omit, he adopts the persona of a capable historian, able to evaluate his material in order to adopt a well thought narrative strategy. ${ }^{28}$ Indeed, the rest of the text immediately alludes again to the source he will be using (Apoc. 5.1):

In caelo quae acta sint audite: fides penes auctorem erit.

Hear what happened in heaven: my source is responsible for the veracity of the story.

24 Cf. Th. 1.22.2. On the ancient historian's preference for eyes over ears in their preliminary researches, cf. Marincola 1997, 63-86. The distinction of course comes from Herodotus, whose position appears to be less naive than it is sometimes presented: cf. Miltsios 2016.

25 Cf. Marincola 1997, 95-117.

26 Cf. Tac. Ann. 15.63.3, about Seneca's last words, that had been published and were apparently widely known.

27 Cf. Duchêne 2017.

28 Cf. how Suetonius introduces his examples of Tiberius' cruelty, at Suet. Tib. 61.3: Singillatim crudeliter facta eius exequi longum est; genera, uelut exemplaria saeuitiae, enumerare sat erit ("It would be too long to list one by one the things he did out of cruelty; it will be enough to enumerate them by types, as examples of his brutality"). 
This sentence works as a diptych with the previous one, by way of the parallel quae acta sint in terris / in caelo, and again plays on how ancient historians inserted details whose credibility was not warranted by themselves, but by some source they consulted - a convenient way to tell borderline stories without being hold responsible for them. ${ }^{29}$

All these characteristics signify that Claudius is not the only one to be represented in the Apocolocyntosis: so are ancient historians. As a consequence, this work, even though not belonging to the historiographical genre, is nevertheless related to historiography: it is not at the center of historical practice, but still clearly linked to it. It is 'historiography in the margins', for its aim is not to tell historical events, but it nevertheless says something about the way they were told in Antiquity. The great advantage of these texts lies in the external point of view they provide: Seneca is not a historian explaining how he works; he rather imitates historians as he sees them work from the outside, as a reader. The Apocolocyntosis then allows us to see how the audience reacted to historical works, especially what was widely known about their conception. And it appears that readers were not blind to the flaws in the texts they read.

This is particularly obvious at the very beginning of the passage where Seneca discusses his sources (Apoc. 1.1):

Haec ita uera si quis quaesiuerit unde sciam, primum, si noluero, non respondebo.

These elements so true, if anyone asks me how I know them, at first, if I am not willing, I will give no answer.

This sentence alludes to the practice of mentioning the sources supporting some peculiar element. For instance, at Ann. 13.20.2, Tacitus explains that he will give the names of the authors he used when presenting divergent versions of the same event. But in spite of such a general claim, in all his work, he actually does so only in one other passage ${ }^{30}$ and mainly omits allusions of this type, most of all the precise identity of his sources. A closer study of the way ancient historians identify and consider the sources they rely upon or criticize shows that a precise identification of where a piece of information came from actually did not matter this much. ${ }^{31}$ Seneca's text confirms it: as a mock historian, he at first plainly refuses to say where he got the story he is about to tell, even if he emphasizes its veracity by starting the sentence with haec ita uera. The clause si noluero introduces an idea of arbitrary: if he is willing, he will give the name; otherwise, he will stay silent

29 Cf. Suet. Nero 34.6, about the emperor's behavior in front of his mother's corpse: Adduntur his atrociora nec incertis auctoribus ("To this are added more terrible details and by well known authors").

30 Cf. Tac. Ann. 14.2.1-2.

31 Cf. Duchêne 2017. 
and nobody will make him utter a word. After that, he contemplates the possibility of speaking, but even then he openly disrespects any 'professional' rule (Apoc. 2.1):

Si libuerit respondere, dicam quod mihi in buccam uenerit.

If it pleases me to answer, I will say what will come to my mind.

This time, the arbitrary is emphasized by the clause si libuerit respondere at the beginning of the sentence and the mock historian still laughs at the request, giving any name that will come to his mind. It is thus not surprising that the witness he chooses to produce is of very questionable credibility (Apoc. 1.2-3):

Tamen, si necesse fuerit auctorem producere, quaerito ab eo qui Drusillam euntem in caelum uidit: idem Claudium uidisse se dicet iter facientem 'non passibus aequis'. velit nolit, necesse est illi omnia uidere quae in caelo aguntur: Appiae Viae curator est, qua scis et Diuum Augustum et Tiberium Caesarem ad deos isse. hunc si interrogaueris, soli narrabit. coram pluribus nunquam uerbum faciet: nam, ex quo in senatu iurauit se Drusillam uidisse caelum ascendentem et illi pro tam bono nuntio nemo credidit, quod uiderit uerbis conceptis affirmauit se non indicaturum, etiam si in medio Foro hominem occisum uidisset.

However, if I must produce an author, ask the one who saw Drusilla go to heaven: he is the same who will say he saw Claudius going 'with unequal steps'. Whether he be willing or not, he must see everything that happens in heaven: he is curator of the Via Appia, through which it is known that the divine Augustus and Tiberius Caesar joined the gods. This man, if you want to question him, only privately will he tell you the story. In front of more people he will never say a word, for, since the day he swore in the Senate he had seen Drusilla go up to heaven and, in exchange for such good news, nobody believed him, he took the solemn oath he would not tell what he saw, even if he had seen a man killed in the middle of the Forum.

The indication about Drusilla's death and the appointment as curator Viae Appiae identifies the witness Seneca claims to have questioned himself as the senator Livius Geminius. But he is precisely not a good witness, for his claim of having seen Caligula's sister go to heaven was a blatant lie, in order to win favor from the emperor. The specification illi nemo credidit underlines the extravagance of his allegations, for no one even feigned to believe him. The quotation from Virgil ${ }^{32}$ non passibus aequis is an additional proof of the fictitious nature of anything he would say about Claudius, for the epic reference is an obvious way to ennoble the late emperor's limping and try to ensure for himself the favour of his heir. In such a context, the presence of the word auctor in the first sentence is rather ironic, for the man is anything but a guaranty.

Seneca is thus not only mocking the topical declarations of Roman historians; he also makes fun of their methodological claims, revealing that everybody knew they were not reliable: they mostly never specified the sources they used and, when they did, the credibility of their information could be quite shallow. One can even wonder 
if the narrator really questioned his witness, for he seems to mainly produce him because he took care of the road that was used for the funeral processions of Augustus and Tiberius. Later after Seneca, in another work of historiography in the margins, ${ }^{33}$ the Historia Conscribenda, Lucian was still denouncing false claims historians sometimes made (Hist. Conscr. 29):

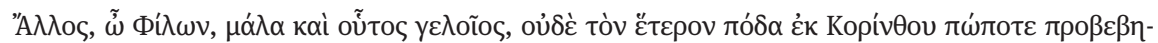

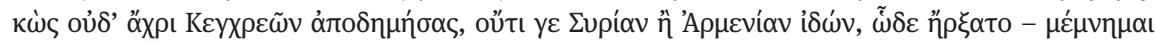





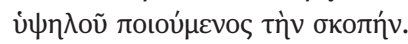

Another man, dear Philon, is also, this time, much ridiculous. Not having ever set foot outside of Corinth, nor left for Cenchreae, nor certainly knowing Syria or Armenia, he began in this way for I remember him: "Ears are less trustful than eyes. Thus I write what I saw, not what I heard." And he had seen everything so accurately that he said [...] and he said he saw this himself as a witness, but making his observation from the safety of a tall tree.

Here again, the historian's declaration and Lucian's criticism concern the Thucydidean insistence on first-hand witnesses, in this case the author himself: ${ }^{34}$ he said he attended the battle, while he had not set foot out of Corinth. The remark about him certainly not knowing Syria or Armenia suggests that he did not even care about gathering information about them..$^{35}$ Nevertheless he insisted on his attend-

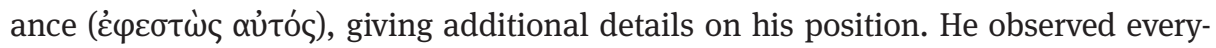
thing safely from a tall tree, precision that enhances the auctoritas of his narrative, for such a standing point supposedly offered him a view of the whole battlefield.

This passage confirms that ancient historians could even lie and add false details in order to increase their own credit. What is most interesting in this case, however, is the final clarification Lucian gives about the circumstances of the reading (ibid.):

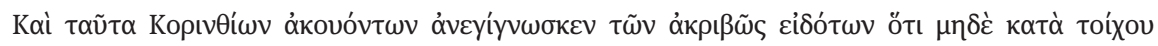

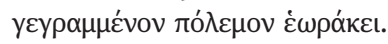

And he read this while he was listened to by Corinthians who knew accurately that he had not even seen from the battlement the war he had written about.

33 Again, the Historia Conscribenda is not a work of history, but tells us something about the way history was written in ancient times.

34 For the links between this work and Thucydides' principles, cf. Billault 2010 and Trédé 2010. 35 The end of the paragraph also denounces his total lack of knowledge about military matters, so he does not even fulfill Polybius' criterium of experience: cf. Luc. Hist. Conscr. 29 and Plb. 12.25 m. For parallels between Polybius and Lucian, cf. Georgiadou / Larmour 1994. Lucian (Hist. Conscr. 37) does not think that one must have experience in order to write history: knowing how things should be and are done is enough. 
The situations of the historian and his audience are similar, yet antithetic in this passage: he refuses to rely upon ear-history, they are listening to him; he said he saw

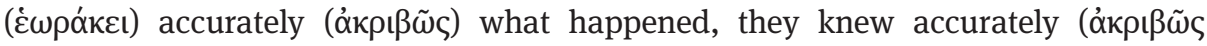
again) that he actually saw nothing ( $\mu \eta \delta \dot{\varepsilon} \dot{\varepsilon} \omega \rho \alpha \dot{\kappa} \varepsilon \mathrm{s})$. The irony lies in the fact that, even though the audience is just listening and never attended the war, they have the only reliable information: he does not know what happened there, they know that what he pretends to report is actually very unlikely to have ever occurred this way.

The main target of Lucian's satire here is of course the failing historian, but his criticism can also be extended to the audience, ${ }^{36}$ for they appear to let him speak as if they did not care about his lies. As a consequence, they too are responsible for the situation. The Apocolocyntosis already alluded to such a hypocrisy on the part of the reader. When refusing to give a name, Seneca comments Quis coacturus est? (Apoc. 1.1: "Who intends to make me?") and, when openly invoking the first person coming to his mind, he adds Quis unquam ab historico iuratores exegit? (Apoc. 1.2: "Who ever demanded of an historian sworn-in witnesses?”). His vocabulary is quite revealing: had he used the simple future coget, one could understand the sentence as implying a low probability of recourse to coercion. But he used the future participle coacturus, which means that it is a question not of probability, but intent. The narrator is perfectly aware that his audience is in no way willing to make him give a name. The verb exegit carries the same implication. Whatever his statements, no one will force him to prove them and the indefinite quis unquam implies that the situation never happened, at any moment, in the history of historiography. As a consequence, Seneca's audience is portrayed here as asking questions, but never really caring about the answers, another characteristic pointed out by his choice of a witness: why select someone credible, if no one actually cares? A known liar can perfectly make do.

Lucian is not as explicit as Seneca about the hypocrisy of the audience. It may come from the fact that his work is not limited to a satire of history writing: ${ }^{37}$ its second part also gives concrete instructions on how history should be written. This is also a way to show the readers how they should evaluate historical texts, after having them laugh at the flaws of failing historians. But it all remains implicit, for Lucian mainly presents the matter from the writing side, speaking rather about the type of readers to aim at, not about how they should be. ${ }^{38}$ He thus explicitly engages

36 Cf. Thompson 1986, 17, about Don Quixote, but relevant for any parody : "Don Quichote peut être considéré comme une parodie des romans de chevalerie et comme une satire dirigée contre le lecteur."

37 For this dimension, see the passage about the invocation of the Muses (Luc. Hist. Conscr. 14) or the death of a soldier (Luc. Hist. Conscr. 26). For the way Lucian uses satire in order to give serious historiographical advice, see Tamiolaki 2015.

38 A good example is Luc. Hist. Conscr. 10, where he says that one should write for those who will read the work $\delta เ \kappa \alpha \sigma \tau \imath \kappa \tilde{\omega} \varsigma$, because they will be as demanding as a money changer. Presenting the 
would-be historians to think about posterity, not contemporary audience. ${ }^{39}$ Such a

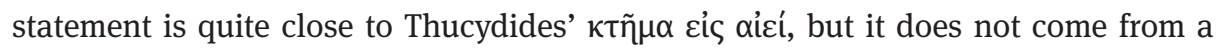
will to produce a work whose worth would be forever admitted: it rather reveals that the reaction of the common public is not a suitable measure to achieve this goal. Lucian specifies the point even before speaking of audiences to come (Hist. Conscr. 10):

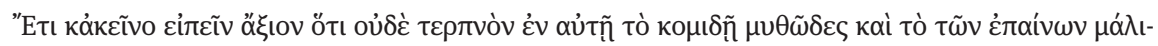

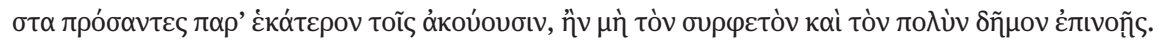

It is also worthwhile to say this: to find in history things that are complete fiction or the type of praise that is very deeply biased does not please the audience either, if you do not care about the lowest and common part of the people.

The problem addressed here is a bit different from the one parodied by Seneca when he declared nihil nec offensae nec gratiae dabitur, for the people to please are not the powerful, but the common: ${ }^{40}$ the alternative is between an immediate success ${ }^{41}$ or one that would be delayed, but last forever.

This type of passages shows that, when writing, ancient historians had in mind the future reactions of their audience and this partly or completely influenced their writing. ${ }^{42}$ As a consequence, by examining what Lucian most strongly rejects, we can have a glimpse at what the common reader was looking for in historical texts. ${ }^{43}$ His insistence on the difference between history and encomium, which would delight not only some general, but also the whole audience (Luc. Hist. Conscr. 7, 9, and 11-12), implies that there must have been a strong inclination to celebration. The passage on the characteristics of poetry as opposed to history also suggests a particular literary taste for high style descriptions and dramatizations. ${ }^{44}$ Tacitus already complained about this trend in his Annales, after he emphasized the political usefulness of knowing what happened and why (4.33.3):

matter from the audience's point of view would have resulted in directly saying that history readers should be as demanding as a money changer.

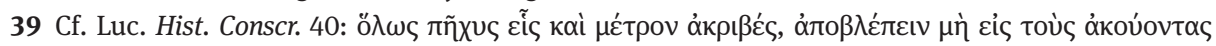

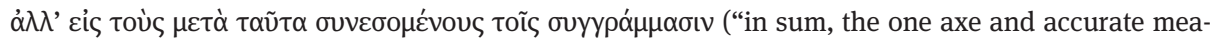
sure is to look forward not to those who listen to you, but to those who, afterwards, will come across your work").

40 Lucian nevertheless addresses the problem of seeking favor from the powerful at Luc. Hist. Conscr. 38, with the same position as Tacitus' sine ira nec studio. On this, see Porod 2009, 30-39. 41 The case of historians writing only to please their public is also addressed by Plb. 12.25j.

42 On this point, cf. also Liotsakis' contribution in the present volume.

43 For how the composition of audience and the different circumstances of public reading influenced Roman historiography, see Wiseman 1981.

44 According to Wiseman (1981, 380 - 381), this characteristic stems from the influence of Greek literature. 
Ceterum, ut profutura, ita minimum oblectationis adferunt. nam situs gentium, uarietates proeliorum, clari ducum exitus retinent ac redintegrant legentium animum; nos saeua iussa, continuas accusationes, fallaces amicitias, perniciem innocentium et easdem exitii causas coniungimus, obuia rerum similitudine et satietate.

However, as useful these elements can be, they also bring very little entertainment. For the living places of peoples, the twists and turns of battles, the glorious deaths of generals catch and renew the attention of readers; but in my case, I present a series of cruel orders, continuous accusations, false friendships, falls of innocents and the same causes for their death, coming across monotony and disgust.

The elements that are listed here quite correspond to Lucian's developments. Situs gentium alludes to a taste for exoticism, uarietates proeliorum to suspense and dramatization and clari ducum exitus to celebration. Tacitus' problem is not with his material, but with its repetitive character (easdem causas; coniungimus; rerum similitudine). As the audience mainly wants to be entertained, not instructed (ut profutura, ita minimum oblectationis adferunt), it is bored (satietate) by the continuous return of the same events and circumstances. ${ }^{45}$

What Seneca's, Tacitus' and Lucian's texts point out is the existence of a dichotomy between what was officially expected of historians (a reliable narration, political lessons, a real knowledge of the subject and no bias) and what the audience actually waited for (entertainment through suspense and dramatization, celebration of deeds and heroes). One could think with Lucian that the divergent expectations were actually those of the lowest part of the public, its educated part really caring about the methodological principles, ${ }^{46}$ but a remark by Tacitus suggests that even the aristocracy was not that uncompromising (Ann. 4.33.4):

Tum quod antiquis scriptoribus rarus obtrectator, neque refert cuiusquam Punicas Romanasue acies laetius extuleris; at multorum qui Tiberio regente poenam uel infamias subiere posteri manent; utque familiae ipsae iam exstinctae sint, reperies qui ob similitudinem morum aliena malefacta sibi obiectari putent.

Moreover, ancient historians seldom faced objections and nobody cares if one more largely celebrated the Roman or the Punic armies; but, of the many that were punished or defamed under Tiberius, some heirs remain; and even when the families themselves are already extinct, you will find people who, because of the similitude of habits, think that the others' misdeeds are reproaches to them.

Both reception problems underlined here suppose from the reader that the historian is necessarily biased. On the one hand, objections linked to the preservation of family memory imply that he should have written according to its interest, not according

45 For an example on how the expectations of different audiences could be handled by Arrian, cf. Liotsakis' contribution.

46 Cf. for instance Wiseman 1981, 387, who distinguishes "mass audiences" and "the educated minority". 
to what happened..$^{47}$ On the other hand, people feeling he is implicitly reproaching them for something do not count on his objectivity either. The starting point of their reflection is that writing about the past is a disguised way to write about the present. Both cases involve upper-class readers, for only they had an interest in preserving the memory of their ancestors and a stainless reputation.

Such a dichotomy is certainly older than Tacitus' time, for it can be found as early as the works of Cicero. Theorizing the writing of history in what is maybe the most famous example of historiography in the margins, ${ }^{48}$ the orator states very strongly the principles to follow (De Orat. 2.62-63):

Nam quis nescit primam esse historiae legem, ne quid falsi dicere audeat? deinde ne quid ueri non audeat? ne quae suspicio gratiae sit in scribendo? ne quae simultatis? haec scilicet fundamenta nota sunt omnibus

For who does not know that the first law of history is to not dare to say something false? Then to not dare not to say something true? To not be suspected of writing in order to win favors? To satisfy a personal hatred? Without doubt, these principles are known to everyone.

The whole passage presents the statements as obvious. Two phrases proclaim that everybody knows this (quis nescit; nota sunt omnibus); two adverbs emphasize that everybody also agrees on the existence of this previous knowledge (nam; scilicet); and the series of rhetorical questions itself implies the obviousness of the remarks. Yet, when Cicero is actually dealing with the writing of history, namely that of his consulate, his attitude is quite different (Fam. 5.12.3):

Itaque te plane etiam atque etiam rogo ut et ornes ea uehementius etiam quam fortasse sentis et in eo leges historiae neglegas gratiamque illam de qua suauissime quodam in prohoemio scripsisti, [...] si me tibi uehementius commendabit, ne aspernere amorique nostro plusculum etiam quam concedet ueritas largiare.

This is why I ask you again and again, straightforwardly, that, at the same time, you bring these events out even with more passion than you may conceive them, and, in this, that you neglect the laws of history, do not despise the famous charm you wrote most suavely about in some proemium, [...] if its recommendation of me is too passionate for you, and give to your affection for me even a little more than the truth allows.

One can argue that the De Oratore and the letter to Lucceius belong to very different genres and that, as a consequence, it is wrong to compare them, ${ }^{49}$ but the similarities between the texts invite us to see them as the two faces of the same coin..$^{50}$ Both in-

47 On this, cf. Wiseman 1979.

48 Cf. Rambaud 1953; Woodman 1988, 70-117.

49 So Rambaud 1953, 17-18. For Rambaud, the letter aims at propaganda, not historiography.

50 Woodman $(1988,70$ - 76) recognizes that the letter is important in order to know Cicero's opinion about the way history should be written, but less important than De Oratore, which is a proper treaty, written seven months after. 
voke the laws of history, perfectly know that truth should be the goal to follow, and deal with prejudice. Given, then, what will be written afterward by Seneca and Lucian, the dichotomy does not appear to be in Cicero's attitude, but in his audience's. The orator knows that, when theorizing, he must speak about methodological principles, just as Seneca is 'forced' by his readers to name his source. When actually dealing with how a historical event should be written, however, his aim is literature, not history. ${ }^{51}$ In the end, the final touchstone remains the public's taste, not methodology: everybody knew this too, for Seneca's readers did not actually care about his witness and Lucian's public did not say anything in front of a blatant lie.

As a consequence, there seems to have been a sort of 'historiographical pact'52 between the historian and his public. Methodological statements were expected in any case, for they guaranteed the auctoritas of the work and the author. ${ }^{53}$ But on the other hand there was an implicit agreement that the main goal should be the pleasure of the reader: $:^{54}$ this is why Tacitus is more anxious about a bored audience than about scarce sources on which to base his narration..$^{55}$ The counter-part on the public's side is then a suspension of disbelief: as far as methodological statements appeared, no further requirement would be made by the common reader in order to verify the coherence between theory and practice. This does not mean historians could lie and elaborate as they pleased, for the verb Cicero uses is ornare, not fingere: he wants Lucceius to resort to inuentio, the art of finding things that are or could be in the story. ${ }^{56}$ It follows that the regime of enunciation in ancient historiography was quite similar, though not identical, to fiction: as no one would complain to a novelist because he/she wrote fiction, most common readers in ancient times apparently did not complain if historical narrations did not contain justifications for every detail or interpretation, because this was not their main criterium of evaluation: what mat-

51 Cf. Wiseman 1981, 381: "The subject matter is contemporary, the aim is expressly political, and yet Cicero's argument throughout is a literary and aesthetic one.” On this point, cf. also the contribution by $\mathrm{D}$. Pausch in the present volume.

52 The expression is modeled on Ph. Lejeune's autobiographical pact (cf. Lejeune, 1996 [1975]), which is mainly based on J.-J. Rousseau's Confessions: when writing an autobiography, the author commits to only speaking about things personally experienced, without omitting, inventing or improving the past; on the other side, the reader has to honestly and fairly judge the life thus presented. 53 In addition to historical conditions, this also explains why Marincola 1997 finds recurring declarations in ancient historians.

54 It does not mean that all historians only had success in mind: the targets of a parody are always successful or widely famous works (cf. Bertrand 2006, 9), so the image it conveys of the parodied genre does not necessarily apply to the whole production.

55 Thinking about the pleasure of the public is not necessarily to be avoided, for it helps the lessons of history to be passed on: cf. the contribution by V. Liotsakis in the present volume.

56 Cf. Wiseman 1981, 388-389, who also quotes Cic. Inv. 1.9: excogitatio rerum uerarum aut ueri similium quae causam probabilem reddant ("[inuentio is] the faculty of finding things that are or seem true, so that they make the cause plausible”). 
tered, at least for the authors of chronological works, ${ }^{57}$ was the continuity and coherence of the narrative $\mathrm{e}^{58}$ and the problems to solve were mainly narrative 'gaps', to be filled by projections or extrapolations. ${ }^{59}$ As a consequence, the way ancient historians and their readers dealt with historical truth was not only a matter of avoiding prejudice, ${ }^{60}$ but also of being in a grey zone, where adjunct elements would be neither false, since nothing, especially coherence and verisimilitude, told the contrary, nor undoutedly true, since nothing positively testified their actual existence. That a Roman audience could apparently very well stand such an uncertainty is additional proof that they had a different relation to the past than us.

This study of works not belonging to the historiographical genre, but nevertheless dealing with it, shows that a step aside from canonical texts leads to a glimpse of how historical practice could be received. It is quite visible in Seneca's Apocolocyntosis, for his intended audience was larger, but only in passing in Lucian's Historia Conscribenda, because he mainly aimed at would-be historians, not their public.

What appears then is an agreement between authors and readers, implicit but clearly known, according to which the auctoritas of the work had to be reinforced by methodological statements, but the main goal was the pleasure of the reader, even if it implied taking liberties with what was strictly proved. This explains the preference for verisimilitude over truth and leads to a peculiar relationship with what we would nowadays consider fiction: whereas today we would call out as falsity anything imagined by a historian, according to ancient standards, if it was plausible, then it was not wrong.

Such an actual practice gave birth to a very peculiar regime of enunciation, under which many 'oddities' fall: not sticking to historical truth was perfectly accepted and only objected when interfering with a version that was more convenient to someone else; extrapolations to add details and dramatize the narration were common, for they enhanced euidentia and delighted the audience; speeches could be entirely rewritten, even when the original had been published. As a consequence, nobody can consider Cicero a hypocrite because he asked Lucceius not to apply to his historical writing the rules later established in his De Oratore: he was perfectly coherent with a practice that was still widely diffused two centuries later.

57 It may have been different for authors of discontinuous narration: cf. Duchêne 2020 for a comparison between Tacitus and Suetonius.

58 Indeed, Lucian mostly deals with the way history should be written (hence the title of the Historia conscribenda), not the methodological principles fo the genre.

59 For the use of such a process in historical enquiry, see Devillers 1995.

60 Cf. Woodman 1988, 81-83. 


\section{Bibliography}

Aveline, J. (2004), "The Death of Claudius", in: Historia 53, 453-475.

Bertrand, D. (2006), "Introduction: état des lieux", in: Seizième siècle 2, 7-19.

Billault, A. (2010), "Lucien et Thucydide", in: V. Fromentin / S. Gottland / P. Payen (eds.), Ombres de Thucydides. La Réception de l'historien depuis l'Antiquité jusqu'au début du XXe siècle, Bordeaux, 199-209.

Devillers, O. (1994), L'Art de la persuasion dans les Annales de Tacite, Latomus 223, Bruxelles.

Devillers, O. (1995), “Tacite, les sources et les impératifs de la narration: le récit de la mort d'Agrippine” in: Latomus 54, 324-345.

Duchêne, P. (2017), "Les critères d'évaluation de Tacite et Suétone face à leurs sources", in: REL 95, 167-182.

Duchêne, P. (2020), Comment écrire sur les empereurs? Les procédés historiographiques de Tacite et Suétone, Ausonius Éditions, Bordeaux.

Fishwick, D. (2002), "The Deification of Claudius" in: CQ 52, 341-349.

Gassino, I. (2011), “Les Histoires vraies de Lucien, de la parodie au manifeste”, in: R. Poignault (ed.), Présence du roman grec et latin, Clermont-Ferrand, 179-191.

Genette, G. (1982), Palimpsestes. La Littérature au second degré, Paris.

Georgiadou, A. / Larmour, D.H. (1994), "Lucian and Historiography: De Historia Conscribenda and Verae Historiae" in: ANRW 34.2, 1448-1509.

Grimal, P. (1989), “Tacite et les présages”, in: REL 67, 170-178.

Householder, F.W. (1944), "ПАР $\Omega \mathrm{IA}$ ", in: CPh 39, 1-9.

Hutcheon, L. (1985), A Theory of Parody. The Teachings of Twentieth Century Arts Form, New York / London.

Lejeune, P. (1996) [1975], Le Pacte autobiographique, Paris.

Marein, M.-F. (2012), “Écriture fictionnelle de l'histoire dans la Vie d'Apollonios de Tyane de Philostrate”, in: B. Morin (ed.), Polumathès. Mélanges offerts à J.-P. Levet, Limoges, $327-342$.

Marincola, J. (1997), Authority and Tradition in Ancient Historiography, Cambridge.

Miltsios, N. (2016), "Sight and Seeing in Herodotus", in: Trends in Classics 8 (1), 1-16.

Moretti, G. (2003), “I difetti fisici di Claudio (Apoc. 5.2-3) e la seconda prova del contrappasso (Apoc. 15.2): Claudio fra tradizione biografica e tradizione menippea”, in: I. Gualandri / G. Mazzoli (eds.), Gli Annei: una famiglia nella storia e nella cultura di Roma imperiale, Como, 141-151.

Porod, R. (2009), "Lucian and the Limits of Fiction in Ancient Historiography”, in: A. Bartley (ed.), A Lucian for our Time, Newcastle / Upon / Tyne, 29-46.

Rambaud, M. (1953), Cicéron et l'histoire romaine, Paris.

Renard, M. (1937), "Suétone et l'Apocoloquintose", in: RBPh 16, 5-13.

Rose, M. (1979), Parody/Metafiction. An Analysis of Parody as a Critical Mirror of the Writing and Reception of Fiction, London.

Tamiolaki, M. (2015), "Satire and Historiography. The Reception of Classical Models and the Construction of the Author's Persona in Lucian's De Historia Conscribenda", in: Mnemosyne 68 (6), 917-936.

Thompson, C. (1986), "Problèmes théoriques de la parodie”, in: Études littéraires, 19, 13-19.

Trédé, M. (2010), "Thucydide et Lucien ou comment lire le traité de Lucien Sur la manière d'écrire l'histoire?", in: V. Fromentin / S. Gottland / P. Payen (eds.), Ombres de Thucydides. La Réception de l'historien depuis l'Antiquité jusqu'au début du XXe siècle, Bordeaux, 191-199.

Whitton, C.L. (2013), "Seneca, Apocolocyntosis", in: E. Buckley / M.T. Dinter (eds.), A Companion to the Neronian Age, Oxford / Malden, MA, 149-169. 
Wiseman, T.P. (1979), Clio's Cosmetics, Leicester.

Wiseman, T.P. (1981), "Practice and Theory in Roman Historiography”, in: History 66, 375-393.

Woodman, A.J. (1988), Rhetoric in Classical Historiography, London. 
